\title{
EFFECT OF FLUORIDE AND GONADAL STEROID DEFICIENCY ON ENAMEL AND DENTIN MINERALIZATION OF FEMALE RATS
}

\author{
EFEITO DO FLUORETO E DA DEFICIÊNCIA DE ESTERÓIDES GONADAIS \\ SOBRE A MINERALIZAÇÃO DE ESMALTE E DENTINA DE RATAS
}

Eliana Mitsue TAKESHITA¹, Sayaka IWAMA, Tatiana Correa da SILVA', Rita Cássia Menegatti DORNELLES², Alberto Carlos Botazzo DELBEM ${ }^{3}$, Kikue Takebayashi SASSAKI ${ }^{4}$

\footnotetext{
1- Undergraduate Student, Araçatuba Dental School, São Paulo State University, Araçatuba, São Paulo, Brazil.

2- Assistant Professor of the Discipline of Physiology of the Department of Basic Sciences, Araçatuba Dental School, São Paulo State University, Araçatuba, São Paulo, Brazil.

3- Associate Professor of the Discipline of Pediatric Dentistry of the Department of Pediatrics and Social Dentistry of Araçatuba Dental School, São Paulo State University, Araçatuba, São Paulo, Brazil.

4- Assistant Professor of the Discipline of Biochemistry of the Department of Basic Sciences, Araçatuba Dental School, São Paulo State University, Araçatuba, São Paulo, Brazil.
}

Corresponding address: Kikue Takebayashi SASSAKI - UNESP - Faculdade de Odontologia de Araçatuba - Rua José Bonifácio, 1193 Bairro Vila Mendonça - Araçatuba - SP Cep.: 16015-050 - Phone +55-18-36363306 - Fax +55-18-36243386 - Email: kts@foa.unesp.br

Received: March 15, 2004 - Returned for modification: April 30, 2004 - Accepted: June 29, 2004

\begin{abstract}
The he aim of this study was to verify the influence of estrogen deficiency on enamel and dentin microhardness of female rats' incisors, as well as the influence of chronic administration of fluoride on that response. Sham or OVX rats drank distilled water or distilled water with $10 \mathrm{ppm}$ fluoride as $\mathrm{NaF}$, for 90 days. The upper incisors were removed and the specimens submitted to microhardness analysis of enamel and dentin. The data were compared by variance analysis and Tukey's test $(\mathrm{p}<0.05)$. There was a significant reduction in the mineralization of crown (7.9\% and $8.1 \%)$ and root $(20.4 \%$ and $25.0 \%)$ in both groups treated with fluoride or distilled water, respectively and an increase $(14.2 \%)$ in the mineralization of coronal dentin after ovariectomy. Fluoride treatment did not cause reduction in enamel mineralization; however, it reduced dentin mineralization following ovariectomy. It was possible to conclude that estrogens directly or indirectly influence the process of enamel and dentin mineralization of female rats' incisors. The results also indicate that enamel and dentin exhibit different responses to fluoride administration.
\end{abstract}

Uniterms: Sodium fluoride; Ovariectomy; Hardness; Osteoporosis.

\begin{abstract}
RESUMO
O

objetivo do trabalho foi verificar se a deficiência de estrógenos causava alteração na microdureza do esmalte e da dentina de incisivos de ratas e se a administração crônica de fluoreto alterava essa resposta. Ratas ovariectomizadas ou shamovariectomizadas receberam para beber água destilada contendo ou não NaF 10 ppm, durante 90 dias. Decorrido este tempo, os incisivos maxilares foram removidos e a microdureza determinada no esmalte e dentina. Os resultados foram submetidos à análise de variância e teste de Tukey $(\mathrm{p}<0,05)$. Constatou-se uma redução significante na mineralização da coroa $(7,9 \%$ e 8,1\%) e raiz $(20,4 \%$ e $25,0 \%)$ nos grupos tratados com fluoreto ou água destilada, respectivamente e um aumento $(14,2 \%)$ na dentina da coroa, após a ovariectomia. O tratamento com fluoreto não impediu a redução da mineralização no esmalte, porém interferiu na dentina diminuindo a mineralização, após a ovariectomia. Concluiu-se que o processo da mineralização do esmalte e da dentina dos incisivos de ratas sofre a ação de estrógenos, de maneira direta ou indireta e que os dois tecidos respondem de maneiras diferentes à administração de fluoreto.
\end{abstract}

Unitermos: Fluoreto de sódio; Ovariectomia; Dureza; Osteoporose. 


\section{INTRODUCTION}

Hormones and growth factors can influence the metabolism of ameloblasts and odontoblasts ${ }^{1,21,23}$. However, the role played by sexual hormones in the process of tooth development remains scarcely investigated. During the 1970s, Spiegel, et al. ${ }^{25}$ (1971) observed that puberty disorders led to mild alterations in tooth development. Other studies have demonstrated that periods of pregnancy and lactation ${ }^{18}$, as well as ovariectomy $(\mathrm{OVX})^{8}$, lead to alterations in the rate of dentin apposition in female rats. Moreover, Jukic, et al. ${ }^{13}$ (2003) detected the presence of estrogen receptors in human dental pulp. Also, Hietala, et al. ${ }^{11}$ (1998) visualized, by immunohistochemical staining, estrogen-receptor-related antigens in the predentinal-odontoblast region of human teeth scrapings.

Ovariectomy in female rats is an experimental model that simulates the post-menopause period in women. It causes osteoporosis with reduction in bone mass and the alterations in its microstructure characterize the osteoporosis and increase the susceptibility to fractures ${ }^{14}$.

Fluoride participates in the process of enamel mineralization in vivo and influences the structure and properties of the mineral formed. During amelogenesis, the presence of free fluoride ions accelerates the formation of apatite crystals ${ }^{27}$. Fluoride replaces the hydroxyl group of apatite and leads to a reduction in the volume of the crystal and increase in the structure stability ${ }^{2}$. However, high concentrations of fluoride may cause disturbances in enamel maturation, leading to subsurface hypomineralization ${ }^{28}$.

The aim of this study was to verify whether the gonadal steroid deficiency and the chronic administration of fluoride can influence the process of mineralization of the enamel and dentin in maxillary incisors of female rats.

\section{MATERIALAND METHODS}

Forty-four female rats (Wistar/160-180g), kept at a lightcontrolled (12 hours of dark -12 hours of light) and temperaturecontrolled $\left(22 \pm 2^{\circ} \mathrm{C}\right)$ environment, were submitted to ovariectomy (OVX group) or sham ovariectomy (sham group)

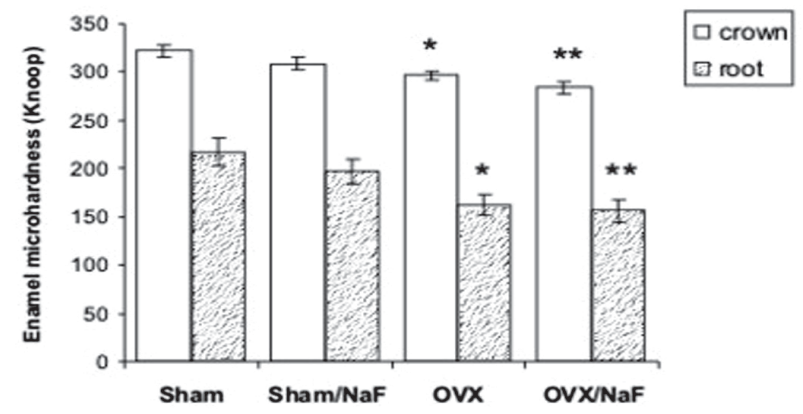

FIGURE 1- Enamel microhardness of the maxillary incisor of sham and OVX female rats treated with fluoride (sham and OVX/NaF) or distilled water (sham and OVX). ${ }^{*} \mathrm{P}<0.05$ vs sham; ${ }^{*} \mathrm{P}<0.05$ vs sham/NaF; $\mathrm{n}=44$ after anesthesia with chloral hydrate ( $4 \mathrm{mg} / \mathrm{Kg}$, IP). The animals received commercially available balanced pellets (Guabi nutrilabor, Mogiana Alimentos S.A.) and water ad libitum. The study design was approved by the Ethics Committee for Animal Experimentation of the Araçatuba Dental School, UNESP. After 15 days, half of each group was given distilled water (sham and OVX groups) or distilled water with $10 \mathrm{ppm}$ fluoride as $\mathrm{NaF}$ (sham/NaF and OVX/NaF groups). The animals were killed with excess ethyl ether inhalation and the maxillary incisors were extracted ninety days after onset of treatment with water or fluoride solution. The incisors were embedded in acrylic resin and the specimens were ground, polished and submitted to microhardness analysis in longitudinal sections, employing the microhardness meter Shimadzu HMV-2.000 ${ }^{\mathrm{TM}}$, with a Knoop indenter under a static load of $50 \mathrm{~g}$ for 10 seconds $^{23}$. Four indents were performed on the middle portion of enamel thickness: the first was performed at $1 \mathrm{~mm}$ from the incisal end; the second at $2 \mathrm{~mm}$ from the first indent, towards the root; the third at $1 \mathrm{~mm}$ from the root apex; the fourth at $2 \mathrm{~mm}$ from the third indent towards the crown. Regarding the dentin, the indents were performed in the same direction as for enamel, at $150 \mu \mathrm{m}$ from the dentin-enamel junction.

After confirmation of the homogeneity of the data, the results were submitted to analysis of variance and Tukey's test on the GMC software ${ }^{5}$, at a significance level of $5 \%$.

\section{RESULTS}

The data from the incisal and middle regions of the crown, as well as on the apical and cervical regions of the root were gathered in a single block to allow a better analysis of the microhardness of enamel and dentin. The means and standard errors (SEM) of enamel and dentin microhardness are graphically displayed (Figures 1 and 2, respectively).

Analysis of enamel microhardness of the maxillary incisors (Figure 1) showed that OVX animals had a significant reduction in the mineralization of crown (7.9\% and $8.1 \%$ ) and root $(20.4 \%$ and $25.0 \%$ ) in both groups treated with fluoride or distilled water, respectively. However, the sham animals did not display any significant alteration in enamel microhardness after chronic administration of fluoride.

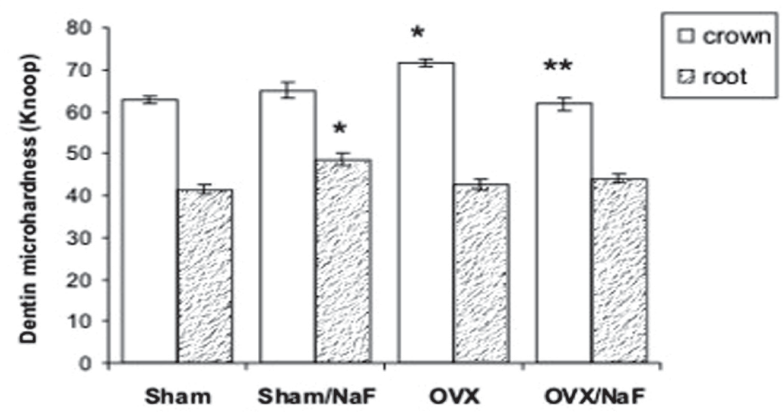

FIGURE 2- Dentin microhardness of the maxillary incisor of sham and OVX female rats treated with fluoride (sham and $\mathrm{OVX} / \mathrm{NaF}$ ) or distilled water (sham and OVX). ${ }^{*} \mathrm{P}<0.05$ vs sham; ${ }^{* *} \mathrm{P}<0.05$ vs OVX; $\mathrm{n}=44$ 
The castrated animals exhibited higher (14.2\%) dentin microhardness at the crown (Figure 2), yet the 90-day treatment with fluoridated distilled water precluded this increase. Moreover, the increase in microhardness of root dentin of rats submitted to sham ovariectomy and treated with fluoride was not observed in the OVX animals who received the same treatment.

\section{DISCUSSION}

There is a lack of investigations on the effects of estrogen deficiency secondary to menopause on the metabolism of odontoblasts or ameloblasts in humans since menopause occurs when teeth are already formed. Therefore, the studies found in the literature are related to investigations conducted in female rats submitted to ovariectomy ${ }^{29}$. Rats' incisors present continuous growth and constitute an interesting model for investigation of the influence of several factors on the different stages of odontogenesis.

In the present study, the reduction in microhardness of the incisor enamel observed in ovariectomized rats (Figure 1) indicates that estrogens may directly or indirectly influence the process of enamel mineralization of these teeth. Estrogen deficiency leads to disturbances in calcium and phosphate homeostasis, which may affect dental tissues ${ }^{10,16,17}$. Microhardness is a physical property that depends on the calcium and protein content in enamel and dentin. According to Lozupone and Favia ${ }^{17}$ (1994), the enamel microhardness in incisors of rats submitted to a calcium-deficient diet is reduced, even though a normal amount of organic matrix has been formed. The estrogen deficiency secondary to ovariectomy leads to a lower intestinal absorption of calcium ${ }^{14}$ and to a decrease in the serum levels of calcium ions ${ }^{12}$. This may explain the deficient enamel mineralization, leading to a reduction in microhardness.

On the other hand, the administration of fluoride at a concentration of $10 \mathrm{ppm}$ in the drinking water for 90 days did not preclude the reduction in enamel microhardness induced by ovariectomy. In fact, it displayed a tendency toward further reduction in enamel microhardness, yet without statistical significance. It is known that fluoride incorporated into enamel crystals affects the subsequent mineralization processes because it reduces the mineral solubility and modulates the ionic composition in the fluid around the mineral ${ }^{3}$. In mature enamel, the matrix is replaced by enamel crystals as proteolytic enzymes (metalloproteinases and serine proteinases) degrade $\mathrm{it}^{20}$. According to Bawden, et al. ${ }^{4}$ (1995), the enamel fluorosis secondary to the intake of high doses of fluoride may be yielded by a disturbance in the removal of amelogenins during the maturation stage, induced by inhibition of proteases by fluoride. DenBesten, et al. ${ }^{7}$ (2002) observed a reduction in the activity of proteases in the enamel matrix in incisors of rats treated with 50 and $100 \mathrm{ppm}$ fluoride in drinking water. On the other hand, Gerlach, et al..$^{9}$ (2000) observed that fluoride $(625 \mu \mathrm{M}$ to $10 \mu \mathrm{M})$ inhibited neither the proteinases activity of the crude enamel matrix extract nor the activity of individual enamel enzymes separated by SDS-PAGE. In fact, the amounts of fluoride required locally to affect an inhibition of amelogenin digestion are unknown. The $10 \mathrm{ppm}$ concentration employed in the present study may not have yielded inhibition of the activity of these enzymes enough to lead to a decrease in mineralization.

Sexual steroids are fundamental for bone maintenance throughout life and the adverse effects of the deficiency of such hormones are noticeable in men and women and in young and old persons. The post-menopause osteoporosis induced by the reduction in the serum concentration of estrogen is characterized by reduction of the bone mass, leading to an increase in fragility and risk of fracture ${ }^{6}$. Laboratory studies have demonstrated that estrogen deficiency caused by ovariectomy in female rats leads to the imbalance between bone formation and resorption causing osteoporosis ${ }^{29}$. Since osteoblasts and odontoblasts have a common mesenchymal origin and both secrete extracellular matrix that will undergo mineralization, the function of both cells is likely to be regulated by the same mechanisms. Moreover, some authors suggest activation of the function of odontoblasts ${ }^{10}$ and osteoblasts ${ }^{29}$ after castration of female rats.

Although enamel in adults is considered a relatively stable tissue, alterations in dentin may occur as secondary dentin formation or dentinal tubules obliteration due to calcium phosphate crystals deposition. The higher dentin microhardness of the maxillary incisor of OVX female rats (Figure 2) perhaps could have been explained by the deposition of inorganic material. Therefore, it may be suggested that postmenopause deficiency of estrogen in women may affect sclerotic dentin, which is observed in the elderly.

The deficiency of estrogen during menopause causes a reduction in the intestinal absorption of calcium, which in turn leads to an increase in the concentration of parathormone $(\mathrm{PTH})^{15,26}$. Yonaga ${ }^{30}(1978)$ studied the effect of this hormone on the mineralization and formation of dentin matrix in incisors of immature rats and observed that these processes were accelerated and did not necessarily occur concurrently when the PTH hypersecretion was caused by a calcium-deficient diet. This may explain the increase in the microhardness of the crown of the incisor of the castrated female rat (Figure 2). Hietala and Larmas ${ }^{10}$ (1992) also observed an increase in dentin formation in female rats following ovariectomy. As already mentioned, Hietala, et al. ${ }^{11}$ (1998) visualized estrogen-receptorrelated antigens in the predentinal-odontoblast region, which could influence that pattern.

Fluoride has been used daily for osteoporosis treatment in women (50 to $75 \mathrm{mg} /$ day). ${ }^{22}$ That dosage is similar to that ingested by rats after drinking water with $10 \mathrm{mg} F / \mathrm{L}$ (the concentration used in this study). According to Shinoda ${ }^{24}$ (1975), 10 ppm F in drinking water did not alter enamel and dentin microhardness of rats' incisors. In the present study, the increase in microhardness of dentin of group OVX was not observed after treatment with fluoride (group OVX/NaF, Figure 2). Moseley, et al. ${ }^{19}$ (2003) observed inhibition of collagen synthesis by odontoblasts after fluoride exposure, which would lead to an alteration of the extracelular matrix and of the dentin mineralization. This may explain the results of the present study.

Standardization of the area for hardness measures in root is difficult as rats' incisors present continuous growth. This could have led to measures in regions closer to the crown. This may 
explain the increase in root microhardness of the incisor of female rats submitted to sham/NaF (Figure 2), when compared to sham group.

\section{CONCLUSION}

The results indicate that the sexual steroids influence the process of mineralization of the enamel and dentin in incisors of female rats. Also, it was demonstrated that enamel and dentin exhibit different responses to fluoride administration. However, further investigations are required to explain the mechanisms involved in this process.

\section{ACKNOWLEDGEMENTS}

E.M.Takeshita thanks CNPq for the CNPq/PIBIC grant.

\section{REFERENCES}

1- Acevedo AC, Chardin H, Staub JF, Septier D, Golberg M. Morphological study of amelogenesis in the rat lower incisor after thyroparathyroidectomy, parathyroidectomy and thyroidectomy. Cell Tissue Res 1996; 283(1):151-7.

2- Aoba, T. The effect of fluoride on apatite structure and growth. Crit Rev Oral Biol Med 1997;8(2):136-53.

3- Aoba T, Fejerskov O. Dental Fluorosis: chemistry and biology. Crit Rev Oral Biol Med 2002;13(2):155-70.

4- Bawden JW, Crenshaw MA, Wright JT, LeGeros RZ. Consideration of possible biologic mechanisms of fluorosis. J Dent Res 1995;74(7):134952.

5- Campos, GM. GMC 2002. Ribeirão Preto: School Dentistry, Avaiable in: http://www.forp.usp.br/restauradora/gmc.html\#gmc. Acessed in feb $21,2003$.

6- Compston J, Sex steroids and bone. Phys Reviews 2001;81:419-47.

7- DenBesten PK, Yan Y, Featherstone JDB, Hilton JF, Smith CE, Li W. Effects of fluoride on rat dental enamel matrix proteinases. Arch Oral Biol 2002;47:763-70.

8- Devlin H, Ferguson MWJ. The rate of incisor dentine calcification and of mandibular growth in the molar region of the ovariectomized rat. Arch Oral Biol 1990;35(1):29-32.

9- Gerlach RF, Souza AP, Cury JA, Line SRP. Fluoride effect on the activity of enamel matrix proteinases in vitro. Eur J Oral Sci 2000;108:4853.

10- Hietala EL, Larmas M. The effect of ovariectomy on dentin formation and caries in adult rats. Acta Odontol Scand 1992; 5:337- 43.

11 - Hietala EL, Larmas M, Salo T. Localization of estrogen-receptorrelated antigen in human odontoblasts. J Dent Res 1998; 77(6):1384-7.

12- Hori M, Uzawa T, Morita K, Noda T, Takahashi H, Inoue J. Effect of human parathyroid hormone (PTH (1-34)) on experimental osteopenia of rats induced by ovariectomy. Bone Miner 1988; 3(3):1939 .
13- Jukic S, Prpic-Mehicic G, Talan-Hranilovc J, Miletic I, Segovic S, Anic I. Estrogen receptors in human pulp tissue. Oral Surg Oral Med Oral Pathol Oral Radiol Endod 2003; 95(3):340-4.

14- Kalu DN, Liu CC, Hardin RR, Hollis BW. The aged rat model of ovarian hormone deficiency bone loss. Endocrinology 1989;124(1):716.

15- Kärkkäinen M, Lamberg-Allardt C. An acute intake of phosphate increases parathyroid hormone secretion and inhibits bone formation in young women. J Bone Miner Res 1996; 11:1905-12.

16- Larmas M, Hietala EL, Similä S, Pajari U. Oral manifestations of familial hypophosphatemic rickets after phosphate supplement therapy: a review of the literature and report of case. ASDC J Dent Child 1991;32834.

17- Lozupone E, Favia A. Morphometric analysis of the deposition and mineralization of enamel and dentin from rat incisor during the recovery phase following a low-calcium regimen. Arch Oral Biol 1994; 39(5):40916.

18- Miller SC, Omura, TH, Smith, LJ. Changes in dentin appositional rates during pregnancy and lactation in rats. J Dent Res 1985 Aug; 64(8):1062-4.

19- Moseley R, Sloan AJ, Waddington RJ, Smith AJ, Hall RC, Embery G. The influence of fluoride on the cellular morphology and synthetic activity of the rat dentine-pulp complex in vitro. Arch Oral Biol 2003; 48(1):39-46.

20- Overall CM, Limeback H. Identification and characterization of enamel proteinases isolated from porcine developing enamel: amelogeninolytic serine proteinases are associated with enamel maturation. Biochem J 1988;256:965-72.

21 - Pirinen S. Endocrine regulation of craniofacial growth. Acta Odontol Scan 1995; 53(3):179-85.

22- Rosen CJ, Bilezikian JP. Anabolic therapy for osteoporosis. J Clin Endocrinol Metab 2001; 86(3):957-64

23- Sassaki KT, Delbem ACB, Santos OAM, Shimabucoro CE, Nakamune ACMS, Bedran-de-Castro JC, Oliveira-Filho RM. Neuroendocrine alterations impair enamel mineralization, tooth eruption and saliva in rats. Pesqui Odontol Bras 2003;17(1):5-10.

24- Shinoda H. Effect of long-term administration of fluoride on physicochemical properties of the rat incisor enamel. Calcif Tiss Res 1975;18:91100 .

25- Spiegel R, Sather H, Hayles A. Cephalometric study of children with various endocrine diseases. Am J Orthod 1971;59:362-75.

26- Tohme JF, Bilezikian JP, Clemens TL, Silverberg SJ, Shane E, Lindsay R. Suppression of parathyroid hormone secretion with oral calcium in normal subjects and patients with primary hyperparathyroidism. J Clin Endocr Metab 1996;70: 951-6.

27- Varughese K, Moreno EC. Crystal growth of calcium apatites in dilute solutions containing fluoride. Calcif Tissue Int 1981;33:431-9.

28- Whitford GM. The physiological and toxicological characteristics of fluoride. J Dent Res 1990; 69(Spec Iss):539-49.

29- Wronski TJ, Cintrón M, Dann LM. Temporal relationship between bone loss and increased bone turnover in ovariectomized rats. Calcif Tissue Int 1988;43:179-83.

30- Yonaga T. Action of parathyroid hormone, with special reference to its anabolic effect on different kinds of tissues in rats (III). Bull Tokyo Med Dent Univ 1978 Dec; 25(4):259-68. 